\title{
Sustainable Cities: Canadian Reality or Urban Myth?
}

\section{Commonwealth Journal of Local Governance \\ Issue 4: November 2009 \\ http:/lepress.lib.uts.edu.au/ojs/index.php/cjlg}

\section{Christopher Stoney}

Centre for Urban Research and Education (CURE)

and School of Public Policy and Administration

Carleton University

Ottawa

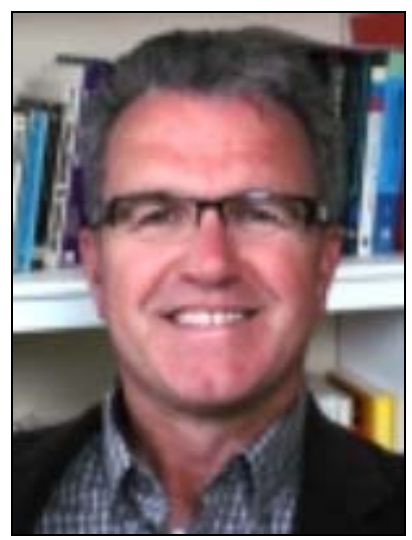

\section{Robert Hilton}

Centre for Urban Research and Education (CURE) and School of Public Policy and Administration Carleton University

Ottawa

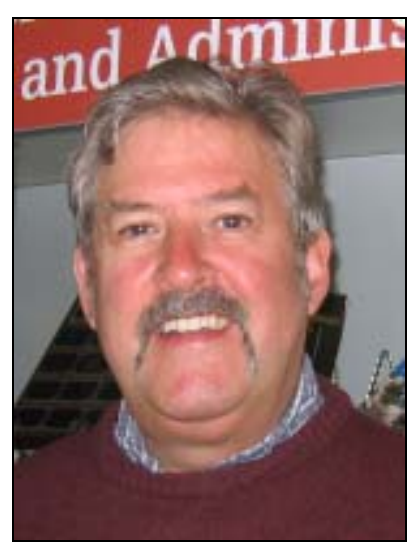

\begin{abstract}
Although it is now over two decades since the Brundtland Commission report (1987) put sustainable development on the political map, concern continues in Canada that the federal government is failing to adequately implement its own commitments to tackling the ecological challenges posed by rapid urban expansion. Our analysis identifies a number of road blocks, missed opportunities and mistakes that have limited progress and many of these
\end{abstract}


are traced back to the failure of national government to empower local municipal governments, as advocated by Brundtland and subsequent international initiatives, in particular 'Agenda 21' which we revisit in some detail as a basis for analysis. As well as reviewing the federal government's role in Canada, the paper explores the potential for more sustainable urban growth in the context of broader reforms.

Keywords: Sustainable development; governance; urban growth; Canada; cities; Canadian federal government

\section{Introduction}

In late 2007, the authors took part in a conference in Ottawa Facing Forward-Looking Back, which invited participants to reflect on the progress made with respect to sustainable development in the two decades since the launch of the Brundtland Commission and its subsequent report (1987). In addition to a retrospective analysis, participants were also invited to propose policies and actions that would accelerate progress towards the kind of sustainable future envisioned by the Brundtland Commission. There was general consensus amongst participants that, in the decades since the report's launch, progress has been disappointing and, consequently, we wanted to identify the specific factors that have impeded sustainable development in Canadian cities as well as suggest areas of continued research that could help to produce more sustainable urban growth over the next two decades and beyond. Our focus is on the federal government of Canada and not the provincial level of government. It was the government of Canada that committed the nation to endorse and implement the principles outlined in Agenda 21 and, to our knowledge, there has been little written specifically about its role.

While the paper focuses on the Canadian context, we believe its findings are relevant to many Commonwealth countries, especially those with federal systems. Our analysis identifies a number of road blocks, missed opportunities and mistakes that have limited progress, and many of these are traced back to the failure of national government to provide adequate support to local governments, as advocated by Brundtland and subsequent 
international initiatives such as 'Local Agenda 21' and the International Council for Local Environmental Initiatives (ICLEI). As well as offering an analysis of the federal government's role in Canada, the paper provides an overview of these initiatives and the potential they provide for more sustainable urban growth.

If sustainability is defined as 'living within the Earth's limits' then it could be argued that the term 'sustainable cities' is an oxymoron. As models of human settlement, cities can be inherently unsustainable black holes of consumption and waste production, with an ecological footprint that far surpasses their geographic parameters. In Canada and around the globe, human settlement patterns are following a powerful trend: for the first time in history those who live in urban centres outnumber rural dwellers. Urban living is now becoming the norm for human habitation with this trend forecast to continue (Fig 1.1).

\section{FIGURE 1.1 World population growth 1950-2020}

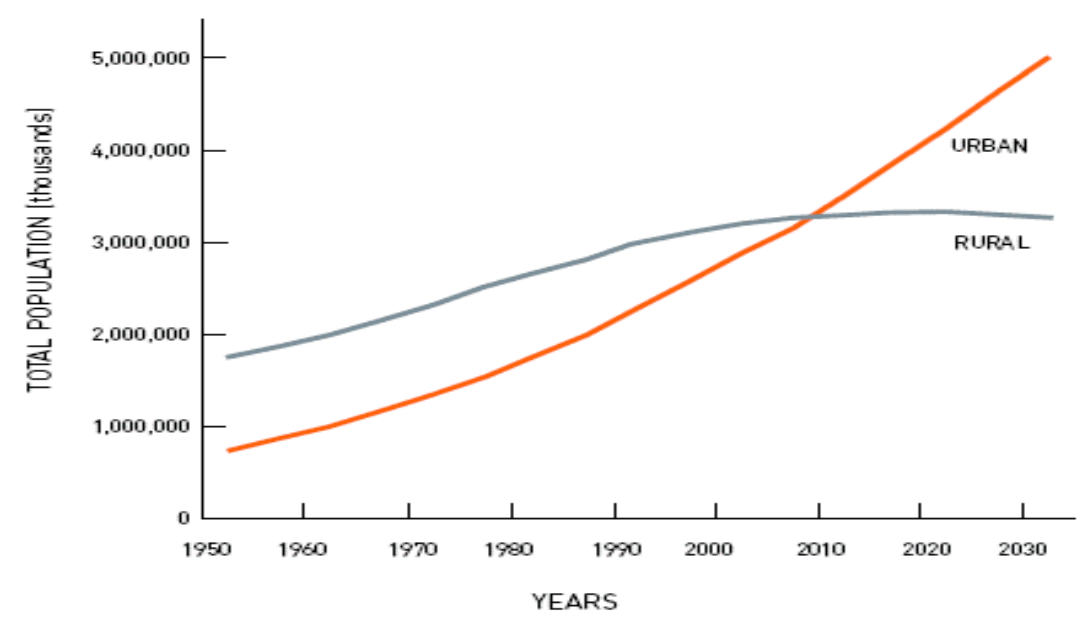

Source: www.humansecurity-cities.org

When the Brundtland report Our Common Future was written, a little over twenty years ago, the effects caused by what it termed 'the urban revolution' were very apparent: “[t]he future will be predominantly urban, and the most immediate environmental concerns of most people will be urban ones” (Bruntland Comission 1987:9.61). Urban regions were already seen as the locus of rapid population and economic growth that was responsible for generating increasing levels of air and water pollution spread far beyond their geographic 
boundaries. Agricultural land was being converted to suburbia, transformed in order to accommodate the housing needs of city workers. With increased demands on the highways and roads from commuting citizens and growth in commercial traffic, snarled transportation systems contributed to increased levels of greenhouse gases and diminished air quality. Solid waste was being transported to neighbouring communities whose land was transformed into 'urban dumps' - landfills that became toxic sources polluting groundwater and the air. Urban regions were consuming ever-increasing quantities of fossil fuels, particularly in order to support transportation and energy generation.

While Brundtland ${ }^{1}$ was able to put sustainable development on the political map championing the idea of a collective or shared search for a sustainable development path based on multilateralism and the interdependence of nations - its messages were delivered in broad principles rather than specifics. As the authors admitted: "We do not offer a detailed blueprint for action, but instead a pathway by which the peoples of the world may enlarge their spheres of cooperation” (ibid., Intro (4)). However, the Brundtland report was a catalyst that launched a wide range of further international initiatives that called for actions beyond the endorsement of broad principles, including the 1992 UN 'Earth Summit' - the Conference on Environment and Development - held in Rio de Janeiro. The Conference launched the Framework Convention on Climate Change, which led to the subsequent Kyoto Protocol on Climate Change. The Rio Summit also created an agenda for the 21st Century that was endorsed by 179 nations. 'Agenda 21' was the UN's blueprint for global transformation that would put nations on the path towards sustainable development, focussing on explicit courses of action needed to cut emissions, limit environmental degradation and transform societies in pursuit of more sustainable development. As well, the International Council for Local Environmental Initiatives (ICLEI), launched in 1990 at the World Congress of Local Governments for a Sustainable Future, focused on the role of local governments in taking action at the municipal level, including the reduction if greenhouse gases and the mitigation of environmental damage that was leading to climate change.

It was through initiatives such as these, rather than Brundtland per se, that concrete actions

\footnotetext{
${ }^{1}$ In this paper, "Brundtland" will be used interchangeably to refer both to the Commission established by the UN as well as the report that was published.
} 
from nation states were sought to move towards more sustainable cities. These initiatives also recognized that neighbourhoods and citizens would need to play a more active role in developing 'resilient' communities through participation and engagement. In this paper we examine what expectations were established in the international community with respect to making cities more sustainable (the intention) and what actions were and were not taken in Canada as a result (the reality). Finally, we look at the implications for local government and propose some areas where more work needs to be done (the future).

\section{The Intention}

\section{Bruntland: a promising start}

Brundtland was given the mandate by the UN to find practical ways of addressing the environmental and developmental problems of the world, focusing on three key objectives: 1) examining the critical environmental and development issues and formulating realistic proposals for dealing with them; 2) identifying and proposing new forms of international cooperation on these issues that would influence policies and events in the direction of needed changes; and 3) raising the levels of understanding and commitment to action of individuals, voluntary organisations, businesses, institutes, and governments.

In its proposals to address the environmental and developmental challenges found in "the natural evolution of the network of settlements,” Brundtland outlined five general lessons learned about spatial strategies for urban development (Bruntland Commission 1987, 9.25). However, the report was cautious about imposing a standardized approach:

Urban development cannot be based on standardized models, imported or indigenous. Development possibilities are particular to each city and must be assessed with the context of its own region. What works in one city may be totally inappropriate in another (Bruntland Commission 1987, 9.36).

However, Brundtland did call for efforts to strengthen the capacity of local governments to deal with the forces of development:

...Local governments have not been given the political power, decision-making capacity, and access to revenues needed to carry out their functions. This leads to frustration, to continuing criticism of local governments for insufficient and ineffective services, and to a downward spiral of weakness feeding on frustration ...To become key 
agents of development, city governments need enhanced political, institutional, and financial capacity, notably access to more of the wealth generated in the city. Only in this way can cities adapt and deploy some of the vast array of tools available to address urban problems ...” (Bruntland Commission 1987, 9.36, 9.39).

In addition to calling for a greater empowerment of local governments, Brundtland recognized that national governments had a role in developing "an explicit national settlements strategy and policies within which innovative and effective local solutions to urban problems can evolve and flourish”(Bruntland Commission 1987, 9.31). While acknowledging that governments usually have some form of "implied urban strategy" described as "implicit in a range of macroeconomic, fiscal, budget energy and agricultural policies” - Brundtland observed that these policies tended to be reactive rather than proactive, often conflicting with each other. Brundtland called for the development of "a national urban strategy [in order to] provide an explicit set of goals and priorities for the development of a nation's urban system and the large, intermediate, and small centres within it” (Bruntland Commission 1987, 9.31). Brundtland also cautioned that "such a strategy must go beyond physical or spatial planning, [and that] it requires that governments take a much broader view of urban policy than has been traditional” (Bruntland Commission 1987, 9.31).

\section{Agenda 21}

Shortly after Brundtland, the Rio Summit in 1992 created an agenda for sustainable development for the 21st Century. Agenda 21 was created as the UN's blueprint for global transformation, a plan to put nations on the path towards sustainable development. Going beyond the broad concepts presented in the Brundtland Report, it introduced detailed expectations of what was involved, "address[ing] the pressing problems of today and also aim[ing] at preparing the world for the challenges of the next century” (Agenda 21 1992, 1.3). While the stark economic and social disparities between 'have' and 'have not' nations was a common theme in its developmental and environmental objectives (à la Brundtland), Agenda 21 pointed out that industrialized countries and those in the developing world both faced environmental challenges, although from different perspectives.

The consumption patterns of cities in industrialized countries were severely stressing the global ecosystem, whereas settlements in the developing world needed more raw material, energy, and economic development simply to overcome basic economic and social problems. Accordingly, Agenda 21 called on all countries to identify the environmental implications of 
urban development and to address these in an 'integrated fashion'.

Agenda 21's comprehensive plan of action to create 'sustainable societies' was multi-tiered international, national and local - and covered a broad range of issues, from combating poverty and changing consumption patterns to combating deforestation and managing fragile ecosystems. The basis for action, objectives, activities and means of implementation for each of these areas included social and economic dimensions, the required conservation and management of resources for development, as well as the steps needed to strengthen the role of major groups. All these actions were to take place within the construct of a 'new global partnership.’

...[The] integration of environment and development concerns and greater attention to them will lead to the fulfilment of basic needs, improved living standards for all, better protected and managed ecosystems and a safer, more prosperous future. No nation can achieve this on its own; but together we can - in a global partnership for sustainable development (Agenda 21 1992, 1.1).

While Agenda 21 reflected "a global consensus and political commitment at the highest level on development and environment cooperation,” (Agenda 21 1992, 1.3) it recognized that successful implementation was "first and foremost the responsibility of Governments." (Agenda 21 1992, 1.3). As a global contract meant to bind governments around the world to make fundamental changes to follow sustainable development paths, it depended on the signatories to follow through with the required actions to put in place "national strategies, plans, policies and processes.” (Agenda 21 1992, 1.3)

Agenda 21 recognized the significant role played by local authorities in making sustainable development happen. National plans, strategies and processes relied on both the willingness and the capacity of local governments to implement them:

Because so many of the problems and solutions being addressed by Agenda 21 have their roots in local activities, the participation and cooperation of local authorities will be a determining factor in fulfilling its objectives. Local authorities construct, operate and maintain economic, social and environmental infrastructure, oversee planning processes, establish local environmental policies and regulations, and assist in implementing national and subnational environmental policies. As the level of governance closest to the people, they play a vital role in educating, mobilizing and responding to the public to promote sustainable development ...Each local authority 
should enter into a dialogue with its citizens, local organizations, and private enterprises and adopt a local Agenda 21 (Agenda 21 1992, 28.1-28.3, emphasis added).

All cities were asked to "develop and strengthen programmes aimed at ...guiding their development along a sustainable path” (Agenda 21 1992, 7.20). The steps needed to follow a sustainable path at the local level were outlined in the chapter "Promoting Sustainable Human Settlement Development” (Agenda 21 1992, 7). The human settlement objective called for improvement "to the social, economic and environmental quality of human settlements and the living and working environments of all people, in particular the urban and rural poor" (ibid., 7.4). It recommended improvements based on "technical cooperation activities, partnerships among the public, private and community sectors and participation in the decision-making process by community groups and special interest groups ..." (Agenda 21 1992, 7.4).

The specific areas to be addressed in promoting sustainable human settlement development included a number of infrastructure-related issues: the provision of adequate shelter; sustainable land-use planning and management; integrated provision of environmental infrastructure (water, sanitation, drainage and solid-waste management); sustainable energy and transport systems; sustainable construction industry activities; and human resource development and capacity-building for human settlement development.

Towards the aim of making improvements in urban areas, Agenda 21 called on all countries to improve the management of human settlement by "adopting and applying urban management guidelines in the areas of land management, urban environmental management, infrastructure management and municipal finance and administration” (Agenda 21 1992, 7.16a). All countries were encouraged to "adopt innovative city planning strategies to address environmental and social issues ... developing local strategies for improving the quality of life and the environment, integrating decisions on land use and land management, investing in the public and private sectors and mobilizing human and material resources, thereby promoting employment generation that is environmentally sound and protective of human health” (Agenda 21 1992, 7.16d).

The steps required to promote sustainable human settlement development were a significant 
challenge for local governments. Accordingly, Agenda 21 called on all countries to "strengthen the capacities of their local governing bodies to deal more effectively with the broad range of developmental and environmental challenges associated with rapid and sound urban growth through comprehensive approaches to planning that recognize the individual needs of cities and are based on ecologically sound urban design practices” (Agenda 21 1992, 7.20c, emphasis added).

In addition, countries were asked to assess the environmental suitability of infrastructure in human settlements and to "develop national goals for sustainable management of waste, and implement environmentally sound technology to ensure that the environment, human health and quality of life are protected” (Agenda 21 1992, 7.39). Towards this aim:

...Settlement infrastructure and environmental programmes designed to promote an integrated human settlements approach to the planning, development, maintenance and management of environmental infrastructure (water supply, sanitation, drainage, solidwaste management) should be strengthened with the assistance of bilateral and multilateral agencies (Agenda 21 1992, 7.39).

Agenda 21 acknowledged that each country's ability to make the necessary changes was “determined to a large extent by the capacity of its people and its institutions as well as by its ecological and geographical conditions” (Agenda 21 1992, 37.1). Therefore, the need for capacity building featured prominently as the underpinning of efforts to make sustainable development happen:

... Capacity building encompasses the country's human, scientific, technological, organizational, institutional and resource capabilities. A fundamental goal of capacitybuilding is to enhance the ability to evaluate and address the crucial questions related to policy choices and modes of implementation among development options, based on an understanding of environmental potentials and limits and of needs as perceived by the people of the country concerned. As a result, the need to strengthen national capacities is shared by all countries (Agenda 21 1992, 37.1).

As a signatory to Agenda 21, Canada had committed to implementing national policies that were needed to support sustainable development. It was expected "to complete, as soon as practicable, if possible by 1994, a review of capacity- and capability-building requirements for devising national sustainable development strategies, including those for generating and implementing its own Agenda 21 action programme” (Agenda 21 1992, 37.4). As will be 
evident in the next section, while the federal government provided some funding for environmental issues there was a noticeable absence of an overall policy framework to guide it.

\section{The Canadian Reality}

\section{The top-down approach: business as usual}

Many of the issues dealing with the implementation of activities in support of sustainable development touch on the responsibilities of local governments, which in Canada fall under provincial/territorial jurisdiction. As Richard and Susan Tindal point out, making a community sustainable involves a significant change management process to reduce the community's impact on the bioregion, “shrinking the size of [its] ecological footprint” (2004, p. 81). Towards this aim, the national government needed to "deploy a host of policy instruments and fiscal incentives to embed ecological factors into the decision making processes of citizens and governments” (Tindal and Tindal 2004, p. 81).

Agenda 21 called for action in several areas of responsibility that are specific to local government and to certain sectors of business (such as manufacturing) that have a significant impact on the environment. These responsibilities include: promoting sustainable human settlement development; integrating environment and development in decision-making; integrating the planning and management of land resources; protecting the quality and supply of freshwater resources (applying integrated approaches to the development, management and use of water resources); promoting environmentally sound management of solid wastes and sewage-related issues; protecting the atmosphere; strengthening the role of nongovernmental organizations (partners for sustainable development); and strengthening the role of business and industry.

To achieve improvements in all of these areas, the federal government needed to create appropriate policy instruments as well as the right financial incentives. When Agenda 21 was signed in June 1992, however, the fiscal capacity of the federal government was under severe pressure and, as the Canadian economy slid into a recession, the federal deficit started to balloon out of control. 
Following the election of the Liberals in 1993, the immediate focus of the government was to stimulate the economy. The Federation of Canadian Municipalities (FCM) had lobbied diligently for federal government funding for municipal infrastructure and the Liberals added this to their election platform. They delivered on the commitment shortly after they assumed power. In 1994: a total of $\$ 2$ billion in new federal spending (increased by another $\$ 400 \mathrm{M}$ in 1997) was allocated to the provinces and territories as contributions to help 'modernize' municipal infrastructure. ${ }^{2}$ The federal government shared (usually one-third) the cost of infrastructure projects that created jobs in the construction sector. The principal driver for investments in municipal infrastructure, however, was founded on Keynesian economics stimulating the economy in communities across the country - rather than focussing on investments needed to support Agenda 21.

As noted above, Agenda 21 recognized the importance of local governments in building sustainable societies and called on all countries to strengthen the capacities of their local governing bodies to deal more effectively with the broad range of developmental and environmental challenges. While the Canadian government made a commitment in the Speech from the Throne ${ }^{3}$ in 1994 to "promote sustainable development as an integral component of decision making at all levels of our society," this was largely rhetoric: it emerged that sustainable development was not really a priority issue for the federal government. By the end of 1994, it began to initiate several expenditure reductions resulting from its Program Review to address the $\$ 40+$ billion deficit. As the Minister of Finance admitted in his Budget Speech, the red ink had to be staunched: it was "crucial that government get its own house in order” (Canada Budget Speech 1995, p. 7). Major budget reductions severely curbed Canada's capacity to meet its domestic and international commitments, including those related to the implementation of sustainable development.

As Gilles Paquet and Robert Shepherd note in their critique of the federal government's belttightening exercise: "What was originally envisaged as a rethinking and reforming of the role of the state within Canada's governance system and the role of the federal government

\footnotetext{
${ }^{2}$ The Canada Infrastructure Works Program (CIWP) consisted of two phases of funding over five years.

${ }^{3}$ Traditionally read out by the Governor General, the Speech from the Throne is prepared by the newly elected federal government and sets out its main priorities for the coming parliamentary term.
} 
within it was already dwarfed by the end of 1994 to an exercise of federal expenditure reduction, and by the end of 1995 to an efficiency-seeking exercise” (1996, p. 32). In the mid 1990’s, the federal government launched its Foreign Policy Review - Canada in the World - that called for the promotion of such 'Canadian values' as "respect for democracy, the rule of law, human rights and the environment” (1995, s.2). The new foreign policy trumpeted the need to export or 'project' these values abroad as a means of achieving "prosperity within Canada and ... the protection of global security” (Foreign Affairs 1995, s.5). The federal government presented sustainable development as "a global concern ... [to which] Canada is committed [including] its interdependent objectives: protecting the environment, social development and economic well-being.” (Foreign Affairs 1995, s. 5). Sustainable development was touted as "a central component of the Canadian value system ...a matter of both common security and good economics” (ibid., emphasis added). As part of its effort to 'brand' Canada through its new foreign policy, the federal government marketed sustainable development not as a goal, but as distinctly Canadian value. ${ }^{4}$

However, while the federal government was making pronouncements that sustainable development was “a central component of the Canadian value system," new capital spending was anathema to the 'small is better government' mantra. The commitment to sustainable development thus appeared to be an expression without substance - a promise bereft of required policy and funding. The 'Canadian values' portrayed in Canada in the World were more simulacrum than reality.

'Sustainable development' was not part of the federal government's vocabulary in either its domestic policy or fiscal frameworks during the 1990s. The 1995-1999 budgets tabled in Parliament made no reference to 'sustainable development.' References to the environment involved support for businesses involved in creating environmental technologies through government programs such as Technology Partnership Canada. Even the rationale for the creation of a new foundation - the Canada Foundation for Innovation (CFI), which had an initial contribution of $\$ 800$ million - was focused on the need to support economic growth. CFI would support the efforts of post-secondary institutions and research hospitals in

\footnotetext{
${ }^{4}$ The phenomenon of nation states 'branding' themselves is explored by Peter van Ham in his paper, "The Rise of the Brand State - The Postmodern Politics of Image and Reputation."
} 
modernizing research infrastructure (Canada Budget Speech 1997, p. 15). CFI's activities focused on health, the environment, science and engineering, but there was no mention of how these activities would address sustainable development. In the words of the Minister of Finance, the future was all about growing the economy:

The Canada Foundation for Innovation is about looking forward. It is about our children. It is about education. In short, it is about investing in the future growth of our economy, making a down payment today for much greater reward tomorrow (Canada Budget Speech 1997, p. 16).

The federal government's agenda with respect to the environment changed significantly as a result of a wave of international pressure to address Climate Change. The Kyoto Protocol on Climate Change required industrialized countries to reduce their collective emissions of greenhouse gases. ${ }^{5}$ In the 1999 Speech from the Throne, the federal government committed to "place greater emphasis on sustainable development in government decision making" (Canada Speech from the Throne 1999, s.6).

With the federal deficit eliminated, the purse strings were loosened in Budget 2000. In the Minister of Finance's speech to the House of Commons, he included nineteen references to the environment. He made the commitment that: "protecting the environment is not an option - it is something that we simply must do. It is a fundamental value - beyond debate, beyond discussion” (Canada Budget Speech 2000, p. 13). The federal government's newfound interest and concern for the environment heralded a big spending spree.

Support for climate change saw the federal government commit \$210 million over three years for the Climate Change Action Fund (CCAF) and other federal energy efficiency and renewable energy programs. As well, $\$ 60$ million (subsequently increased by another $\$ 50$ million in 2003) was used to create the Canadian Foundation for Climate and Atmospheric Sciences (CFCAS), which became the main funding body for university-based research on climate, atmospheric and related oceanic work in Canada. ${ }^{6}$

\footnotetext{
${ }^{5}$ Under the Kyoto Protocol, Canada agreed to reduce annual emissions over the period 2008-2012 to a level 6 percent below actual emissions in 1990. As the Minister of the Environment Stéphane Dion admitted in 2005, however: "Canada is indeed far behind but Canada is not giving up." (Dion 2005). ${ }^{6}$ Established as an autonomous foundation, the Canadian Foundation for Climate and Atmospheric Sciences is "a network of institutes which will link researchers from across the country in order, for
} 
The Federation of Municipalities as well as La Coalition pour le renouvellement des infrastructures du Québec had again lobbied successfully for more funding from the federal government for municipal infrastructure. Budget 2000 committed over $\$ 2$ billion to "strengthen the basic physical infrastructure which underpins so much of the economic activity of both rural and urban Canada” (Canada Budget Speech 2000, p. 16). Unlike the earlier Canada Infrastructure Works Program, however, there was now a call for a new focus on 'green infrastructure. ${ }^{7}$ Program funding would result in the "enhancement of the quality of the environment, support long-term economic growth, improve community infrastructure, increase innovation and use of new approaches and best practices [and make] more efficient

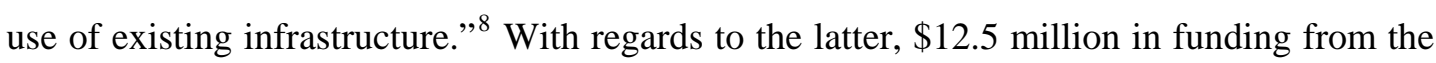
program was directed to create the National Guide to Sustainable Municipal Infrastructure: Innovations and Best Practices, involving a partnership between the federal government and the Federation of Canadian Municipalities. This unique initiative represented a step towards the community capacity building called for by Agenda 21, although the federal government's rationale for committing the funding made no reference to that proposal. The project ran until 2006 when a request for further funding from the federal government was denied by the Harper Conservatives.

The federal government also committed \$600 million from Budget 2000 for improvements to provincial highways. The objective of the new program - the Strategic Highways Infrastructure Program (SHIP) - was to "improve the quality of life of Canadians by promoting safer and more environmentally sustainable transportation ... [and] make the Canadian surface transportation system more reliable, efficient, competitive, integrated, and sustainable” (Transport Canada 2007). Transport Canada defined ‘sustainable transportation’ as: “ ... one that is safe, efficient and environmentally friendly ... a transportation system that respects the natural environment” (2009). However, beyond the broad principle that

instance, to further our understanding of the impact of climate change and air pollution on human health.” (Canada Budget Speech, 2000).

${ }^{7}$ While Budget 2000 provided the funding there was no clear definition as to what 'green' meant at the time. The policy, as such, came later. The Infrastructure Canada Program that flowed the funds eventually used the definition that 'green municipal infrastructure' would apply to those projects that "improve the quality of our environment and contribute to our national goals of clean air and water."

${ }^{8}$ Program details are available at Hhttp://www.infrastructure.gc.ca/icp/ 
"governments, industry and individuals must work together to integrate economic, social and environmental considerations into decisions affecting transportation activity” (2009), Transport Canada does not have a policy framework to explain what this means nor has it explained how miles of new asphalt could be 'environmentally friendly'. This is not surprising given the Auditor General's criticism of the federal government for its failure to have a highway policy and for the practice of committing significant amounts of money to highway projects in a ‘vacuum’ (Auditor General of Canada 1998).

While interest in the environment featured prominently in Budget 2000, the major reason driving this interest was based in economics. As the Minister of Finance observed:

...Those nations which demonstrate how to truly integrate environmental and economic concerns will forge new tools and develop new technologies that others will have to adopt. Tremendous rewards await those nations that get there first, for those which do it best ... Technology is key (Canada Budget Speech 2000, p. 13).

Under Budget 2000, the federal government pursued this theme aggressively, providing an additional \$900 million in funding for the Canada Foundation for Innovation. It identified CFI as "one of the cornerstones of our plan to support the new economy" (ibid., p. 12). As an independent corporation, CFI operates at arm's length from the government under the guidance of an independent board of directors, much to the chagrin of the Auditor General. ${ }^{9}$ The federal government made further increases to CFI's operating capital, raising its total funding to $\$ 3.65$ billion, which allowed it to expand financial support for the scientific and technological communities (CFI 2005). In Budget 2007, the Harper Government added another \$510 million to CFI.

CFI's mandate is to fund research infrastructure needed to carry out research that creates "the necessary conditions for sustainable, long-term economic growth-including the creation of spin-off ventures and the commercialization of discoveries” (CFI 2005, p. 4). The CFI recognizes the importance played by research in creating a sustainable environment, providing funding for research in areas such as solid waste, water supply, transport systems,

\footnotetext{
${ }^{9}$ The Auditor General has sharply criticised the federal government's practice of creating and funding entities outside the reach of her oversight. She has raised the issue in several reports (see OAG 2002:ch.1, and OAG 2005b:ch. 4).
} 
renewable energy sources, recycling, rational utilization of energy, protection of soil and groundwater, pollution and protection of the environment, infrastructure and general planning of land-use. These areas of research have a potential significant impact on local governments, although this is not acknowledged in CFI's literature. The opportunity to tie this research to the aims of Brundtland and Agenda 21 would appear to have been lost to the pursuit of economic growth.

The mandate of CFI is clearly focused on building research capacity "to ensure our international competitiveness in those domains in which Canada is, or has the potential to be, the world leader ... [and] translating the knowledge and ideas being generated by the research enterprise into new products and services that will enhance prosperity and our quality of life” (ibid., p. 3). While CFI claims that it has funded infrastructure projects in sixty-two municipalities across Canada that have "contributed to the development of community based technology clusters and to the transfer of new knowledge and ideas to industry" (CFI 2005, p. 3), it remains unclear as to how these results have contributed to sustainable development in Canada and we know of no independent or government-led attempts to measure outcomes in these specific areas. Any such measurement would be difficult to undertake and would, ideally, require non-CFI funded research.

In its 2004-2005 annual report, CFI set an objective to "ensure benefits to Canada (by) promot[ing] networking, collaboration, and multidisciplinary approaches and collaborating with other funding agencies and provincial governments to optimize the impact of research investments, and identify longer-term needs” (CFI 2005, p. 25). As well, CFI intends to "demonstrate the value of investments [by] examin[ing] the impacts of CFI-funded projects in different parts of Canada ... [and to] partner with other funding agencies within the federal and provincial governments to ensure that good and relevant information is being collected in evaluation and outcome assessment of CFI-funded projects” (CFI 2005, p. 25). While CFI's preoccupation with economic prosperity and ensuring that Canada is "internationally competitive in research and innovation" is important, so too is determining how past results have contributed to sustainable development.

In Budget 2000, the federal government created another foundation - Sustainable 
Development Technology Canada (SDTC) - to "foster innovation by helping companies develop new technologies and bring them to market in areas such as clean burning coal and new fuel cell developments” (Canada Budget Speech 2000, p. 14). Registered as a not-forprofit, non-share Capital Corporation under the Canada Business Corporations Act, SDTC began operations in November 2001 with an initial funding allocation of \$100 million. SDTC's mission is “to act as the primary catalyst in building a sustainable development technology infrastructure in Canada ...contribut[ing] measurably to the federal government's goals for reducing emissions and improving air quality while at the same time fostering technologies that advance the competitive position of Canadian companies in the global marketplace” (SDTC 2004, p. 1).

SDTC bridges the funding gap in the innovation chain for the development of sustainable development technologies, filling the gap that the private equity community has not addressed: "historically, SD technologies were considered to be more capital-intensive with longer development cycles than other technologies” (SDTC 2008a). SDTC applies its funding to support the development of new technologies in several areas: energy exploration, production, transmission and distribution; power generation; energy utilization (industrial, commercial and residential sectors); buildings and processes; transportation; forestry; agriculture; waste management; emission controls and enabling technologies. In 2004, the federal government expanded the Foundation's mandate to include soil and water technologies and increased its total funding to \$550 million.

To be consistent with its nomenclature, SDTC claims that all projects that are funded support the goals of sustainable development: "ensuring that resources are not consumed faster than they can be replenished, supporting prosperity and growth and respecting the values, culture and human needs of communities" (SDTC 2008b). At the same time, however, SDTC acknowledges in its 2004 Annual Report that its contributions to the development and demonstration of technologies do not have proven but rather "potential returns [that] can be measured in terms of environmental, economic and social benefits” (SDTC 2004, p.12, emphasis added).

While an in-depth study of SDTC is beyond the scope of this paper, it would again appear 
that the primary focus of it's funding is to spur economic growth: "fostering technologies that advance the competitive position of Canadian companies in the global marketplace”(SDTC 2004, p. 1). The federal government's rationale for creating SDTC is reminiscent of Paul Hawken et al, who champion the idea of "exploring the lucrative opportunities for businesses in an era of approaching environmental limits ... It is about the possibilities that will arise from the birth of a new type of industrialism ... [under which] society will be able to create a vital economy that uses radically less material and energy" (2000, p. 2). These observations closely resemble those made by the Minister of Finance during his Budget Speech in 2000 (cited earlier) when he stated: “[t]remendous rewards await those nations that get there first, for those which do it best ... Technology is key” (Op. cit.).

SDTC promotes its many successes in contributing to the development of new technology: reducing development, market and financial risk; building private sector partnerships and leveraging funding; helping to build a critical mass of sustainable development technology developers; and increasing the pool of available sustainable development technologies. However, it needs to find ways of marketing these technologies and has recognized its shortcomings in this regard. SDTC has set out to "increase the number and rate of uptake of SD technologies into the marketplace across Canada, providing national benefits." (SDTC 2007, p. 4). While SDTC funded projects could provide positive benefits for local communities in Canada, these benefits could only accrue through their timely diffusion in the market place. One potential means of accomplishing this is through the Green Municipal Fund (GMF), another arms-length financing initiative created by the federal government in 2000.

As noted earlier, in the time leading up to Budget 2000, the Federation of Canadian Municipalities and La Coalition pour le renouvellement des infrastructures du Québec lobbied the federal government for funding to help local communities use innovative technology - 'green infrastructure' - that would generate measurable environmental, economic, and social benefits in addressing their environmental challenges. The federal government agreed to provide \$125 million as an endowment to the FCM to encourage local governments to apply new technologies in energy and water savings, urban transit, waste 
diversion and renewable energy. The federal government doubled its funding for GMF in 2001 and increased it by another \$300 million in 2005. This arrangement is significant because it involves direct funding by the federal government for the FCM through the establishment of an endowment fund. By becoming involved in the delivery of a federal program, the FCM, a representative association of local governments, may run the risk of compromising its independent platform from which to assess and, if necessary, criticize federal policy.

\title{
Whither a national urban strategy?
}

As long as the federal government continues to pour billions of dollars into various municipal infrastructure programs, it seems remarkable that its approach is devoid of a strategy to support municipal governments in the long-term. While Brundtland called on nations to develop a national urban strategy and Agenda 21 called on all countries to identify the environmental implications of urban development and to address these in an integrated fashion, the federal government's investments in municipalities focus on growth, jobs and economic stimulation in the absence of a strategy for sustainable approaches to growth. It operates with a decades-old National Highway Transportation Policy and there is no national transit strategy. As a report commissioned for the federal government observed:

\begin{abstract}
...The major infrastructure investments in cities are fragmented amongst various departments with little co-ordination ... At present, there are no mechanisms in place to ensure that federal infrastructure investments are not working at cross-purposes with one another, or to systematically make informed decisions based on a comprehensive understanding of the economic and environmental implications of an investment decision (Toronto Star 2004).
\end{abstract}

The Federation of Canadian Municipalities (FCM), which has lobbied hard for decades for funding assistance from the federal government to deal with the local 'infrastructure deficit', has also concluded that transfer programs are not the answer:

...While ad hoc contributions from the federal government have been useful, they have not provided the long term structural solution needed to address the infrastructure deficit for good (FCM 2006, p. 38).

In the next section of the paper, we consider the implications of the development of a national strategy and what could be done to promote the sustainable agenda by the local and 
upper tier governments in Canada. 


\section{The Future}

As the last 20 years have shown, the federal government's rhetoric in support for sustainable development has largely failed to translate into action sufficient to allow the country to achieve the kinds of reforms required by Brundtland and Agenda 21. If Canadian cities are to become more sustainable, a number of issues will need to be addressed. While we cannot pursue each of these in detail, we believe that further research and initiatives in the following areas can help to promote sustainable urban development.

\section{Municipal Revenues}

Both Brundtland and Agenda 21 argued that local governments have a significant role in dealing with the forces of growth and in making the changes necessary to implement decision-making that supports sustainable development. Creating access to more of the wealth that is generated to deal with these challenges is a major component of capacity building. However, while Brundtland called for national governments to strengthen the capacity of local governments to deal with the forces of development - enhancing political, institutional, and financial capacity, notably though access to more of the wealth generated in the city - Canada's larger cities continue to be the engines of wealth creation but remain excluded from the significant sources of government revenues that are generated.

As Tindal and Tindal observe: “As long as municipalities must continue to rely on the property tax as their main source of revenue, it is inevitable that they will devote considerable effort to attracting growth and development and this expanding their tax base” (2004:166). Municipal governments are grossly under-funded, which is reflected in their continuing dependency on increasing revenues through sprawl development and relying on servicing this development through road building rather than developing progressive public transportation alternatives. Evidence of deferred maintenance for public assets and resulting decaying infrastructure is found in all Canadian cities. The fiscal revenues shared by municipalities require root and branch reform to reduce dependency on property tax and developer fees. In addition to the regressive nature of property taxes, developer charges do not fully reflect the life-cycle costs of infrastructure, requiring municipalities to assume a liability disproportionate to the contribution calculated in the developer fee. 
Until 2009, the federal government enjoyed many years of healthy surpluses (e.g. nearly \$14 billion in 2006-7), in contrast to the fiscal challenges facing the large urban centres of the country ${ }^{10}$. Rather than providing transfers to local governments, a structural solution that rebalances the revenues available to them is required. While municipal governments were once able to rely on revenues from personal and corporate income taxes, they suddenly and permanently lost access to them during World War II. Under the Wartime Tax Rental Agreement with the federal government, the provinces - as well as municipal governments temporarily renounced their rights under the Constitution to collect personal and corporate income taxes and succession duties.

In 1962, the provinces ended the practice of renting out their taxing powers and in 1967 resumed collecting their own taxes (La Forest 1981, pp. 31-32). However, at the end of the tax rental agreements with the federal government, the authority to levy income tax was never reinstated for municipal governments. As Kitchen observed, "[s]ince the signing of the first agreement, no municipality in Canada has levied a municipal income tax... [i]ndeed, current provincial legislation states that local governments cannot implement a municipal income tax” (1982, p. 781).

The federal government has the opportunity to make a lasting solution to address the 'vertical imbalance' in the fiscal framework. There is clearly a need for a permanent injection of capital that grows with the economy, particularly for cities and city-regions. Rather than continuing temporary 'revenue transfers,' the federal government could offer a transfer of tax points ${ }^{11}$ as a percentage of income tax to those municipalities identified in provincial legislation as bone fide recipients of this revenue. With provincial consent, municipal governments could 'piggyback' the administration of municipal income taxes onto

${ }^{10}$ According to the FCM, the 'infrastructure gap' is estimated to be $\$ 123 \mathrm{bn}$ and the share of total tax revenues taken by municipalities is only $8 \%$ compared to $42 \%$ raised by provincial governments and $50 \%$ raised by the Federal Government.

${ }^{11}$ A tax point has been used as a permanent transfer of income taxing capacity from the federal government to the provincial governments. The federal government reduces its basic tax rate by a specific percentage and the provinces increase theirs by an equivalent amount, thereby leaving total federal and provincial tax unaffected. Tax points can be applied to personal income tax (PIT) or to corporate income tax (CIT). 
the existing provincial income tax system ${ }^{12}$.

While advocating the restoration of municipal income tax, however, we are not calling for a pan-Canadian, universal approach. As Slack, Bourne and Gertler have argued:

It is not appropriate to give more taxing authority to all municipal jurisdictions in the province. Large cities and city-regions are best suited to take advantage of new taxing authority; smaller cities are unlikely to be able to raise sufficient revenues from some of these sources to make the effort worthwhile” (2003, p. 42, emphasis added).

\section{Land use}

Since Confederation, Canada has grown by giving away land for settlement. Land was viewed as a cheap commodity to entice immigrants to the country, particularly in opening up the west to development. Canada's huge land mass has contributed to the myth-like sense that land is and always will be plentiful. As Jennifer Reid notes, "[t]he task of constructing identity is ... given form within any people's mythology; for myths are those articulations that express how any particular reality has come into being” (Mircea Eliade 1963, cited in Reid 1997, p. 3). The development of the country continues to be served by the myth that 'high density living' is both unnecessary and counter cultural.

Canadians have been slow to change their attitude and behaviour in this regard. Like most developed countries, Canada's economy is based on continued accumulation and expansion, but it is facing specific challenges and barriers. As Canadian cities become urban centres and then urban regions, their ecological footprints continue to expand significantly. The Calgary Foundation reported recently in its first Vital Signs report card that this is particularly evident in cities such as Calgary:

Calgary's ecological footprint is one of the world's largest being unsustainable at 9.86 hectares per person - if people around the world had our ecological footprint, it would take five earth-sized planets to sustain us all (Calgary Foundation 2007).

In spite of some notable provincial efforts to contain sprawl ${ }^{13}$, land use planning in Canada continues to be based on the model of market driven peripheral growth, although this form of

\footnotetext{
${ }^{12}$ Income taxes could also be used in conjunction with revenues from sales taxation and user fees for services such as water and garbage collection.
} 
destructive development can be curbed through financial disincentives (realistic pricing) placed on greenfield development beyond the urban boundary. When municipal revenues are no longer dependent upon opening up green space for development (reducing what Pierre Filion refers to as "fiscal dependence on growth" and the "attentiveness" of municipal politicians and officials to requests from developers) incentives can be shifted to higher density development (Filion 2002, cited in Bradford 2004, p.76). Incentives for reclaiming brownfield sites would also reinforce these trends.

\section{Do we really need to move people?}

Despite the forecasts made about the impact of the knowledge based economy and its influence in contributing to the "death of distance" as described by Frances Cairncross (1997) reference needed, our cities remain locked in promoting an elaborate system of transportation infrastructure that moves people - some over fairly large distances - from home to work. This model is based on an approach from the late 19th and $20^{\text {th }}$ centuries that saw the development of streetcar systems, buses, subways, light rail and - predominantly the construction of roads and highways. In addition to being choked with single-occupancy vehicles, the latter are also being burdened by commercial traffic. The cost to build and operate the infrastructure related to moving people is unsustainable. The amount of energy consumed in moving people is staggering. As GreenApple Canada recently reported: "Greenhouse gas emissions from transport are growing faster than any other sector and may have pushed Kyoto targets out of reach for many cities” (2007, p. iii).

While not all sectors of the economy can operate without having workers in conventional work places (the hospitality and service industry, retail, and emergency services to name a few) there are potential opportunities for employers to allow 'knowledge employees' to telework, thereby reducing the need for commuting and for contributing to congestion in the transportation system. However, telework need not be limited to working at home. There are opportunities for municipalities to work in partnership with the private sector that would allow employees to work closer to home in community owned and operated facilities - such

\footnotetext{
${ }^{13}$ For example, the Ontario Government's 'Places to Grow' Act (2005) and the Greenbelt Act (2005); development charges levied on a development by development basis as in municipalities in BC and parts of Ontario (e.g. Markham).
} 
as libraries - that are equipped as 'information portals'. Through leasing arrangements, it would be possible for municipal governments to develop combined library and community recreation facilities which offer space on site to allow employees to access teleconferencing and other on line services. In spite of the existence of the necessary technology, the scope to reduce the need to move people has not been fully exploited.

In Ottawa, the federal government has recently begun to locate some of its departments and offices in different parts of the city. As the city's major employer, it is expected this policy will reduce the pressure on the downtown and save money on rental space as well. This initiative makes economic and environmental sense and, in many cases, the private sector could follow this example, further incentivised by lower rents and and perhaps lower property taxes on businesses, although this would increase the need for alternative forms of municipal funding as discussed earlier.

\section{Strategic infrastructure use}

Too often local 'parochial' interests dominate urban planning instead of focusing on the broader needs of the city. Municipal amalgamation appears to have increased these tensions by combining rural and urban wards. Rural voters are often reluctant to see their taxes go to urban capital projects such as light rail transit. With the exception of Vancouver, where councillors are elected citywide, metropolitan councillors in Canada are elected by ward and, as a result, tend to focus on ward-specific rather than citywide issues and interests.

The tendency for 'log rolling' behaviour among municipal politicians, whereby votes are exchanged in return for political favour or support for specific projects, can also undermine the development of solutions that would better suit broader public interest in spending public money more prudently and strategically. Rather than capital accumulation, whereby municipal services are expanded through the development of more public assets, there may be opportunities to explore solutions that offer multiple purposes and benefits. For example, as mentioned above, the development of mixed-use facilities that combine a public need (libraries) with a business need (portal services for teleworking) offer new ways of achieving multiple goals. Other examples include the development of public spaces (libraries, 
recreation and community centres) within buildings that offer both commercial and residential space, thereby achieving a higher density for public infrastructure.

\section{Reporting Progress}

In spite of some progress, comprehensive measures and reporting of urban sustainable development have not been established on a Canada-wide basis. Rather, measures of effectiveness remain firmly entrenched with the bottom line. As a consequence, progress is not transparent to the public. It is also impossible for politicians to be held accountable for the performance of their cities with respect of sustainable development. The application of cost benefit analysis, which includes full environmental impacts and costs, is not well developed in Canada.

The application of standard reporting measures would be a welcome addition. The recent GreenApple Canada report awarded Ottawa-Gatineau a ' $B$ ' grade, lauding the City of Ottawa's 2020 Official Plan and planning undertaken in support of the estimated population increase. Unfortunately, the good grade ignores the subsequently elected council's short-term thinking that undermines Ottawa 2020 and the demise of a light rail transit project. ${ }^{14}$ There is an urgent need to develop measures that are founded on credible evidence and allow comparisons to be made between cities (Portland, 2003, c.f., ch. 2).

\section{Governance}

As cities morph into city regions governance becomes increasingly difficult to coordinate. No single level of government appears to have adequate powers to provide integrated thinking on issues such as transportation and pollution prevention. While there are valid concerns about 'multiple-tier' governance and the risk of confused accountability (from the taxpayers' perspective), there needs to be a broader discussion about the governance of urban regions to ensure that decision making better incorporates the principles of sustainable development. For example, the loss of agricultural lands adjacent to urban centres as a result of creeping exo-urban settlements (suburbia) can only be arrested through a broad form of

\footnotetext{
${ }^{14}$ See for example, Stoney and Hilton (2007) 'Ottawa's LRT System: Dreams, Delusions and Deceptions', Revue Gouvernance, June 2007 Spring 2007, Vol.4, Issue 1, pp. 2-22,

Hhttp://www.revuegouvernance.ca/index.php
} 
governance that sees beyond municipal boundaries and incorporates a regional perspective. While Toronto and Vancouver, notably, have experimented with regional government it is still the exception rather than the norm in Canadian cities ${ }^{15}$.

\section{Public Engagement}

Agenda 21 observed that, as the level of governance closest to the people, local governments play a vital role in educating, mobilizing and responding to the public to promote sustainable development. Accordingly, it called for each local authority to enter into a dialogue with its citizens, local organizations, and private enterprises and adopt a local Agenda 21. In spite of some municipal experimentation, however, governance in Canada remains top down with little emphasis on public participation and neighbourhood planning (Harcourt et al 2007, Milroy, 2002, Hamel 2002). While many Canadians are genuinely committed to making their cities more sustainable, there is little scope for community priorities to be expressed or to influence the traditional model of market driven growth. Infrastructure Canada is currently funding research into neighbourhood planning and community engagement at the municipal level, and with the 'gas tax' transfers from federal to local governments for major infrastructure investment facilitating increased local discretion, now may be an ideal time for the federal government to promote and facilitate local participation in place-based decisionmaking (Bradford 2004, 2004a).

\section{Conclusion}

In this paper we have examined the expectations that were established in the international community with respect to making cities more sustainable, what actions were taken in Canada as a result, and some areas where more work needs to be done if urban sustainability is to be seriously pursued. Overall, we conclude that many of the actions that were needed to make our cities more sustainable have either not been taken or were not well executed. As Johanne Gélinas, Canada’s former Commissioner of the Environment and Sustainable Development, stated in her Office of the Auditor General of Canada (OAG) status report to the House of Commons in 2005: “...the government continues to talk a good line about

\footnotetext{
${ }^{15}$ We have recently written a conference paper examining Metrolinx in Toronto and Translink in Vancouver: 'Canada's City Regions' Time to Rethink Local Governance'. A draft can be found at https://conference.cbs.dk/index.php/irspm/irspm2009/paper/view/256/146
} 
sustainable development and sometimes commits financial resources, but often fails to adequately implement its own commitments” (OAG 2005a, s.6). We feel this statement provides an accurate and succinct summary for Canada, some twenty years after Brundtland.

If this is to change twenty years from now, then many of the reforms we have proposed will need to be implemented. The reforms needed are major and so the political, cultural and economic barriers to change will remain significant. However, other countries have demonstrated that urban sustainability can be vigorously pursued and Brundtland, Agenda 21 and numerous reports since, have provided an excellent blueprint for how to proceed. As Canadians come to appreciate the full consequences of not pursuing urban sustainability, the prospects for meaningful change are enhanced, but the next decade will be crucial. If Canadian cities continue to grow in an unsustainable manner the constraints imposed by existing forms of development or 'path dependency' will rule out many options for achieving sustainability in the future.

The top-down approach favoured by Canada's federal and provincial governments has proved to be unresponsive and largely ineffective in the pursuit of sustainable development in our urban centres. The status quo, as described in the paper, will ensure that Canadian cities continue to develop in line with the traditional North American model based on sprawl and high-energy use. If Canada is to respond effectively to the urban challenges ahead then local government will have a crucial role to play and, as recognised in Brundtland and Agenda 21, this means they must be afforded the power, resources and responsibility to pursue sustainable urban growth.

\section{References:}

Agenda 21 1992, The United Nations Conference on Environment and Development (Earth Summit) held in Rio de Janeiro, United Nations, Geneva, accessed 16 March 2009, $<$ http://www.un.org/esa/sustdev/documents/agenda21/english/agenda21toc.htm>.

Auditor General of Canada 1998, Report: Transport Canada, Investment in Highways, Chapter 25, December 1998, accessed 27 November 2009, <http://www.oagbvg.gc.ca/internet/English/parl_oag_199812_25_e_9331.html>. 
Auditor General of Canada 2005, Report of the Commissioner of the Environment and Sustainable Development to the House of Commons, prepared by Williams T, Science and Technology Division, accessed 27 November 2009, <http://www.parl.gc.ca/information/library/PRBpubs/prb0512-e.html>.

Bradford, N 2002, Why Cities Matter: Policy Research Perspectives for Canada, Canadian Policy Research Networks, Ottawa.

Bradford, N 2004, 'Global Flows and Local Places: The Cities Agenda', in G. Bruce Doern (ed.), How Ottawa Spends 2004-2005: Mandate Change in the Martin Era, pp. 70-88, McGill-Queens University Press, Montreal.

Bradford, N 2004, 'Place Matters and Multi-level Governance: Perspectives on a New Urban Policy Paradigm', Policy Options February 2004 Vol. 25 No. 2, Canadian Policy Research Networks, Ottawa.

Brundtland Commission 1987, Our Common Future, World Commission on Environment and Development, Oxford.

Cairncross, F 1997, The Death of Distance: How the Communication Revolution Will Change Our Lives, Orion Publishing, London.

Canada Budget Speech 1995, Delivered by the The Honourable Paul Martin, P.C., M.P. Minister of Finance, February 27, 1995, Department of Finance, Canada.

Canada Budget Speech 1997, Delivered by the The Honourable Paul Martin, P.C., M.P. Minister of Finance, February 18, 1997, Department of Finance, Canada.

Canada Budget Speech 2000, Delivered by the The Honourable Paul Martin, P.C., M.P. Minister of Finance, February 28, 2000, Department of Finance, Canada.

‘Canada falling short on Kyoto agreement: Dion’ CTV.ca Budget, 29 November 2005, accessed 26 November 2009, $<$ http://www.ctv.ca/servlet/ArticleNews/story/CTVNews/20051128/climate_kyoto_051128?s_n ame=budget2006\&no ads $>$.

'Federal Role in Urban Infrastructure’, Toronto Star, October 25, 2004, page number unknown.

Federation of Canadian Muncipalities (FCM) 2006, Building Prosperity from the Ground Up: Restoring Municipal Fiscal Balance, FCM, Ottawa, accessed 16 March 2009, $<$ http://www.fcm.ca/english/advocacy/fiscalim.pdf $>$.

Foreign Affairs and International Trade Canada (DFAIT) 1995, Canada in the World, DFAIT, Ottawa, accessed 16 March 2009, < $\underline{\text { http://www.dfait-maeci.gc.ca/foreign_policy/cnd-world/menu- }}$ en.asp>.

Gilles, P and Shepherd, R 1996, 'The Program Review Process: A Deconstruction', in Swimmer G. (ed.), How Ottawa Spends 1996-97: Life Under The Knife, Carleton University Press, Ottawa, pp. 39-72.

GreenApple Canada 2007, Smart Transportation Ranking Report: September 21 2007, University of British Columbia, Vancouver, accessed 16 March 2009, $<$ http://www.appletonfoundation.org/Files/GreenApple\%20Canada\%202008\%20SMART\%20T ransportation\%20Ranking\%20Report.pdf $>$.

Hamel, P 2002, 'Urban Issues and New Public Policy Challenges: The Example of Public Consultation Policy in Montreal' Urban Affairs: Back on the Policy Agenda, Andrew et al (ed.), McGill-Queen's University Press, Montreal \& Kingston.

Harcourt, M, Rossiter, S, and Cameron, K, 2007, City Making in Paradise: 9 Decisions That Saved Vancouver, Douglas and McIntyre, Vancouver. 
Hawken, P, Lovins, A, and Lovins, L H, 2000, Natural Capitalism: Creating the Next Industrial Revolution, Little Brown and Company, Boston.

Kitchen, H 1982, 'Municipal Income Taxation - A Revenue Alternative?' Canadian Tax Journal, vol. XXX, no. 5, September-October, p. 781.

La Forest, G V 1981, ‘The Allocation of Taxing Power Under the Canadian Constitution' in 2d. Canadian Tax Paper No. 65, May 1082, Canadian Tax Foundation, pp. 31-32.

Milroy, B M 2002, ‘Toronto’s Legal Challenge’ in Urban Affairs: Back on the Policy Agenda, Andrew et al (ed.), pp. 157-178, McGill-Queen’s University Press, Montreal \& Kingston.

Office of the Auditor General of Canada (OAG) 2002, Report of the Auditor General of Canada to the House of Commons: 2002 April, Minister of Public Works and Government Services Canada, Ottawa, accessed 16 March 2009, <http://www.oagbvg.gc.ca/internet/English/parl_oag_200204_e_1133.html>.

Office of the Auditor General of Canada (OAG) 2005a, 2005 February Status Report of the Auditor General of Canada, Minister of Public Works and Government Services Canada, Ottawa, accessed 16 March 2009, <http://www.oagbvg.gc.ca/internet/English/parl_oag_200502_e_1121.html>.

Office of the Auditor General of Canada (OAG) 2005b, 2005 September Report of the Commissioner of the Environment and Sustainable Development, Minister of Public Works and Government Services Canada, Ottawa, accessed 16 March 2009, <http://www.oagbvg.gc.ca/internet/English/parl_cesd_200509_00_e_14947.html>.

Portland, K E 2003, Taking Sustainable Cities Seriously: Economic Development, the Environment, and Quality of Life in American Cities (American and Comparative Environmental Policy), MIT Press, Boston.

Reid, J 1997, 'A Society Made by History: The Mythic Source of Identity in Canada,' in Canadian Review of American Studies, vol. 27 (1), pp. 1-20.

Sustainable Development Technology Canada (SDTC) 2004, 2004 Annual Report, SDTC, Ottawa, accessed 16 March 2009, <http://www.sdtc.ca/en/news/annual_reports.htm>.

Sharpe, V 2007, Mandate, Partnering for Real Results (Presentation by President and CEO of SDTC), accessed 30 November 2009, $<$ http://sefi.unep.org/fileadmin/media/sefi/docs/pub_finance/Vicky_Sharpe.ppt $>$.

Sustainable Development Technology Canada (SDTC) 2008a, About SDTC, Innovation Chain, STDC, Ottawa, accessed 16 March 2009, <http://www.sdtc.ca/en/about/innovation.htm>.

Sustainable Development Technology Canada (SDTC) 2008b, About SDTC, SDTC Profile, STDC, Ottawa, accessed 16 March 2009, < $\underline{\text { http://www.sdtc.ca/en/about/index.htm>. }}$

Slack, E, Bourne, L S, and Gertler, M 2003, Vibrant Cities and City-Regions: Responding to Emerging Challenges, University of Toronto, Toronto.

Stoney, C and Hilton, R 2007, 'Dreams, Deception and Delusions: Derailing Ottawa’s Light Rail Transit System', Revue Gouvernance, vol. 4, (1), pp. 2-22.

Tindal, R C and Tindal, S N 2004, Local Government in Canada, 6th ed. Nelson College Indigenous, Scarborough.

Transport Canada 2007, Evaluation of the Strategic Highway Infrastructure Program, Departmental Evaluation Services, Transport Canada, Ottawa, accessed March $25^{\text {th }}$ 2009,

$<$ http://www.tc.gc.ca/media/documents/corporate-services/ship.pdf $>$. 
Transport Canada 2009, Contact Information and Frequently Asked Questions, Transport Canada, Ottawa, accessed March $25^{\text {th }} 2009$,

<http://www.tc.gc.ca/programs/environment/MOST/contactAndQuestions.htm>.

Van Ham, P 2001, 'The Rise of the Brand State - The Postmodern Politics of Image and Reputation', Foreign Affairs, vol. 80(5), accessed 27 November 2009,

<http://www.foreignaffairs.org/2001/5.html $>$. 